\title{
Comparative evaluation of maize (Zea mays L.) genotypes based on distinctness, uniformity and stability (DUS) testing using physiological and morphological characters
}

\author{
Divya Prakash Singh* and Shailesh Marker \\ Department of Genetics and Plant Breeding, Sam Higginbottom Institute of Agriculture, Technology \& Sciences, \\ Allahabad-211007 (Uttar Pradesh), INDIA \\ *Corresponding author. E-mail: d.p.singhag@gmail.com
}

Received: July 24, 2015; Revised received: February 6, 2016; Accepted: April 21, 2016

\begin{abstract}
A major challenge facing those involved in the testing of new plant varieties for Distinctness, Uniformity and Stability (DUS) is the need to compare them against all those of 'common knowledge'. A set of maize inbred lines was used to compare how morphological and physio- logical characterization described variety relationships. An experiment was carried out to evaluate test of Distinctiveness, Uniformity and Stability using 26 physiological and 12 morphological characters. Minimum days for $50 \%$ tasseling (50.66 and 50.66 days), minimum days for $50 \%$ silking (53.66 and 53.66 days), minimum days for anthesis silking interval (3.0 and 2.6 days), maximum tassel branching (22.66 and 21.66), maximum cob height $(89.70$ and $89.16 \mathrm{~cm})$ and maximum cob length $(16.96$ and 17.75 $\mathrm{cm}$ ) were recorded in genotype AAIMS-1 in both experiments (2011 and 2012 respectively) and maximum cob width $(12.51$ and $13.11 \mathrm{~cm})$ and maximum number of grain rows per cob (12.66 and 12.66) were recorded in genotype AAIMS-2 in both experiments (2011 and 2012 respectively). But maximum plant height (155.13 and $153.71 \mathrm{~cm}$ ), minimum days for maturity (86.00 and 88.00 days), maximum grain yield per plant (72.80 and $72.00 \mathrm{~g})$ and maximum 100 seed weight $(21.51$ and $20.96 \mathrm{~g})$ were recorded in genotype AAIMS-2 and AAIMS-1 respectively in both experiments conducted at experimental farm of Department of Genetics and Plant Breeding, Sam Higginbottom Institute of Agriculture, Technology \& Sciences during the year 2011 and 2012 respectively.
\end{abstract}

Keywords: DUS, Genotypes, Maize, Morphological characters, Physiological characters

\section{INTRODUCTION}

Maize is a cereal crop which is cultivated widely throughout the world and has the highest production among all the cereals. USA is the largest producer of maize in the world, followed by China and Brazil. The worldwide production of maize was more than 960 MnMT in 2013-14. It is an important food staple in many countries and is also used in animal feed and many industrial applications. The crop has tremendous genetic variability, which enables it to thrive in tropical, subtropical, and temperate climates (Anonymous, 2014).

The area and production of maize in India is $9.58 \mathrm{mha}$ and $24.35 \mathrm{mt}$ respectively with productivity ranging about $2707 \mathrm{~kg} / \mathrm{ha}$ (2014-2015). In Uttar Pradesh, the area and production during 2014-15 was 0.74 mha and 1236.6 tonnes respectively with productivity of 1671 $\mathrm{kg} / \mathrm{ha}$. Maize is grown worldwide on an approximately 161 million ha annually with a production of 685 million metric tons (Agriculture Statistics at a Glance, 2015).

DUS Testing is one of the important criteria to test inbred lines for distinctness, uniformity and stability. DUS Testing of cultivars is one of the requirements for granting Plant Breeders Rights (PBR) and it is conducted according to national guidelines prepared on the basis of UPOV guidelines. The system accepted and in operation in a large number of countries is as provided by UPOV. Information is, thus, generated on the basis of internationally accepted and followed norms, thereby providing a basis for appropriate comparison of materials identified under the national agricultural research system (NARS) alongside materials from other sources (Yadav and Singh, 2010). Morpho-physiological characters have been used to study the genetic diversity in maize (Beyene et al., 2005). In addition, morphological characters have been recognized to constitute universally undisputed descriptors for varietal characterization of crop species and establishing the distinctness, uniformity and stability (DUS) of crop species in Plant Variety Protection (PVP) systems (Begum and Kumar, 2011). The traits used in assessing crop variety for DUS have been carefully selected taking into account the plasticity of morphological characteristics and thus the efficient for comparing varieties (Law et al., 2011). However the measurement of morphological and physiological traits is expensive, requiring more space, time consuming (Smykal et al., 2008) and traits 
and stability (DUS) testing using physiological and morphological characters.

\section{MATERIALS AND METHODS}

Morpho-agronomic studies of maize genotypes on UPOV harmonized characteristics; generally as per DUS test guidelines were undertaken.

Seed materials used and test conditions: Four maize genotypes which were taken from Department of Genetics and Plant Breeding, Sam Higgin bottom Institute of Agriculture, Technology \& Sciences (Deemed-to-be -University) Allahabad (U.P.), were grown at Central Research Field, SHIATS, Allahabad. Two evaluation trails were conducted during kharif season of 2011 and 2012.

Characteristics used for morphological and physiological evaluation: UPOV's DUS (International Union for the Protection of New Varieties of Plants- Distinctiveness, Uniformity and Stability) test guidelines were generally followed beginning from the trial layout to recording of the last field related observation. In UPOV many morphological and physiological characteristics to be recorded in maize at different stages of plant growth are given. Keeping this in view, a total number of 38 characteristics were selected for observations. Characters considered for testing of inbred lines (Sujay and Singh, 2011) are given in Table 1.

Data analysis: Analysis of variance of different morphological characteristics, visually assessed characteristics, analysis of variance of measurable characteristics was done for distinctiveness in maize, analysis for uniformity in maize, and analysis for stability in maize.

\section{RESULTS AND DISCUSSION}

Morphological characters: The mean performance of different morphological characteristics is depicted in table 2 which revealed that minimum days required for $50 \%$ tasseling and for $50 \%$ silking wear 50.66 and 53.66 days in genotype AAIMS-1 in both the years of study. Further maximum tassel branching, maximum cob height and maximum cob length 22.66, 21.66, $89.70,89.16$, and $16.96,17.75$ respectively were also recorded in genotype AIMS-1 in both years, these results were in accordance with Olakojo and Olaoye, 2005, Salami et al., 2007; and Nazir et al., 2010. The maximum cob width and maximum number of grain rows per cob 12.51, 13.11 and 12.66 respectively were recorded in genotype AAIMS-2 in both years. But maximum plant height, minimum days for maturity, maximum grain yield per plant and maximum 100 seed weight $155.13,153.71 \mathrm{~cm}, 86.00,88.00,72.80,78.00 \mathrm{~g}$ and $21.51,20.96 \mathrm{~g}$ days were recorded in genotype AAIMS-2 in 2011 maximum grain yield were reported by Beyene et al,. 2005 and in AAIMS-1 in 2012 and earliest anthesis silking interval (ASI) was recorded in genotype AAIMS-1 in 2012 and late ASI was recorded in genotype MRM-3777 in 2011. The results of present studies also got support from the findings of Jha and Ghosh (1998).

Physiological characters: Twenty two visually assessed characteristics of maize was also evaluated which has given in table 3 and no variation was found among these characters. States of different measurable physiological characteristics with over two years mean performance of four measurable physiological characteristics have been presented (Table 4).

Analysis of distinctiveness: Significant differences were observed among the genotypes for all the characteristics. Analysis of distinctiveness was also evaluated which revealed that all the genotypes were showing distinctiveness with respect to each other (Table 5).

Analysis of uniformity: For uniformity analysis twenty six characteristics were studied. Out of which, twenty two visually assessed characteristics did not exhibit any variation during the two years of study. All four measured characteristics were uniformity for tassel length in these genotypes is at the lowest level of number of occasions at which the within years standard deviation exceeds the UPOV criterion (Table 6).

Analysis of stability: After the analysis for stability it was recorded that twenty two visually assessed characteristics exhibited stable performance over both the years of experiment as there was no variation in expression of these characteristics over the years. Four measurable characteristics were subjected to statistical analysis for stability by comparison of respective values of PCV and GCV based of pooled morphological data (Table 7). Hence the characters leaf: width of blade and ear: diameter without husk characters were considered relatively less stable as compared to other measurable characters viz. Tassel: length of main axis above lowest side branch and Plant: ear placement. Akande and Lamidi 2006; Olaoye, 2009 reported that the two years could be due to differences in environmental conditions which vary from year to year.

In this study, distinctiveness, uniformity and stability tests were evaluated with 13 morphological and 26 physiological characters and all morphological characters did not show any variation in their states of expression over two years study. But in case of physiological characters, four measurable physiological characters were present in which two characters viz. leaf: width of blade and ear: diameter without husk characters showed comparatively greater magnitude of differences between GCV and PCV showed which indicated the larger role of environmental factors in bringing variation for these characters in stability test.

\section{Conclusion}

In present study, significant differences were observed among the genotypes for all the characteristics for distinctiveness. In case of uniformity, twenty six characters had observed, out of which twenty two characters did not exhibit any variation but four measured characteristics were uniformity for tassel length in 
Table 1. Characters used in DUS testing of maize.

\begin{tabular}{|c|c|c|c|c|c|}
\hline S.N. & Characteristics & States & Note & Stage of observation & $\begin{array}{l}\text { Type of assess- } \\
\text { ment }\end{array}$ \\
\hline \multicolumn{6}{|c|}{ A. Physiological characteristics } \\
\hline \multirow[t]{2}{*}{1} & \multirow{2}{*}{$\begin{array}{l}\text { Leaf: Angle between blade and } \\
\text { stem }\end{array}$} & Narrow & 3 & \multirow[t]{2}{*}{ Beginning of anthesis } & \multirow[t]{2}{*}{ VG } \\
\hline & & Wide & 7 & & \\
\hline \multirow[t]{2}{*}{2} & \multirow[t]{2}{*}{ Leaf: Attitude of blade } & Erect & 1 & \multirow[t]{2}{*}{ Beginning of anthesis } & \multirow[t]{2}{*}{ VG } \\
\hline & & Drooping & 9 & & \\
\hline \multirow[t]{2}{*}{3} & \multirow{2}{*}{$\begin{array}{l}\text { Leaf: Anthocyanin colouration } \\
\text { of blade \& sheath }\end{array}$} & Absent & 1 & \multirow{2}{*}{$\begin{array}{l}\text { Anthesis halfway- medium } \\
\text { milk }\end{array}$} & \multirow[t]{2}{*}{ VG } \\
\hline & & Present & 9 & & \\
\hline \multirow[t]{2}{*}{4} & \multirow[t]{2}{*}{ Leaf: Hairs on the blade } & Absent & 1 & \multirow[t]{2}{*}{ Beginning of anthesis } & VG \\
\hline & & Present & 9 & & \\
\hline 5 & Leaf: Anthocyanin colouration & Absent & 1 & Anthesis halfway- medium & VG \\
\hline & of auricle & Present & 9 & milk & \\
\hline 6 & Leaf: Hairs on the auricle & Absent & 1 & Anthesis halfway & VG \\
\hline & & Present & 9 & & \\
\hline 7 & Leaf: Width of blade & Narrow $(<8 \mathrm{~cm})$ & 3 & Medium milk & MS \\
\hline & & Medium $(8-9 \mathrm{~cm})$ & 5 & & \\
\hline & & Broad $(>9 \mathrm{~cm})$ & 7 & & \\
\hline 8 & Stem: Anthocyanin colouration & Absent & 1 & Anthesis halfway- medium & VG \\
\hline & of stem & Present & 9 & milk & \\
\hline 9 & Stem: Anthocyanin colouration & Absent & 1 & Anthesis halfway & VG \\
\hline & of brace roots & Present & 9 & & \\
\hline 10 & Tassel: time of anthesis & Very early (<45 days) & 1 & Anthesis halfway & VG \\
\hline & & Early (45-50 days) & 3 & & \\
\hline & & Medium (50-55 days) & 5 & & \\
\hline & & Late ( $>55$ days) & 7 & & \\
\hline 11 & Tassel: Anthocyanin colouration & Absent & 1 & Anthesis halfway & VS \\
\hline & at base of glume & Present & 9 & & \\
\hline 12 & Tassel: Anthocyanin colouration & Absent & 1 & Anthesis halfway & VS \\
\hline & of glumes excluding base & Present & 9 & & \\
\hline 13 & Tassel: Anthocyanin colouration & Absent & 1 & Anthesis halfway & VG \\
\hline & of anthers & Present & 9 & & \\
\hline 14 & Tassel: Density of spikelets & Sparse & 1 & Anthesis halfway & VG \\
\hline & & Dense & 9 & & \\
\hline 15 & Tassel: Attitude of lateral & Straight & 1 & Anthesis halfway & VG \\
\hline & branches & Curved & 5 & & \\
\hline & & Strongly curved & 9 & & \\
\hline 16 & Tassel: length of main axis & Short $(<120 \mathrm{~cm})$ & 3 & Caryopsis watery ripe & MS \\
\hline & above lower side branch & Medium $(120-130 \mathrm{~cm})$ & 5 & & \\
\hline & & Long $(>130 \mathrm{~cm})$ & 7 & & \\
\hline 17 & Ear: Anthocyanin colouration of & Absent & 1 & Anthesis halfway & VG \\
\hline & silks & Present & 9 & & \\
\hline 18 & Plant: Ear placement & Low & 3 & Medium milk & MS \\
\hline & & Medium & 5 & & \\
\hline & & High & 7 & & \\
\hline 19 & Ear: Time of silk emergence & Very early (<48 days) & 1 & Anthesis halfway & VG \\
\hline & (50\% plants) & Early (48-53 days) & 3 & & \\
\hline & & Medium (53-58 days) & 5 & & \\
\hline & & Late ( $>58$ days) & 7 & & \\
\hline 20 & Ear: Anthocyanin colouration of & White & 1 & Caryopsis loosening day- & VG \\
\hline & glumes of cob & Light purple & 2 & time & \\
\hline & & Dark purple & 3 & & \\
\hline 21 & Ear: Type of grain & Flint & 1 & Caryopsis hard (can no & VG \\
\hline & & Semi flint & 2 & longer be dented by thumb- & \\
\hline & & Dent & 3 & nails) & \\
\hline 22 & Ear: Colour of top of grain & White & 2 & Caryopsis hard (can no & VG \\
\hline & & White with cap & 3 & longer be dented by thumb- & \\
\hline & & Yellow & 4 & nails) & \\
\hline & & Yellow with cap & 5 & & \\
\hline & & Orange & 6 & & \\
\hline & & Brown & 7 & & \\
\hline
\end{tabular}




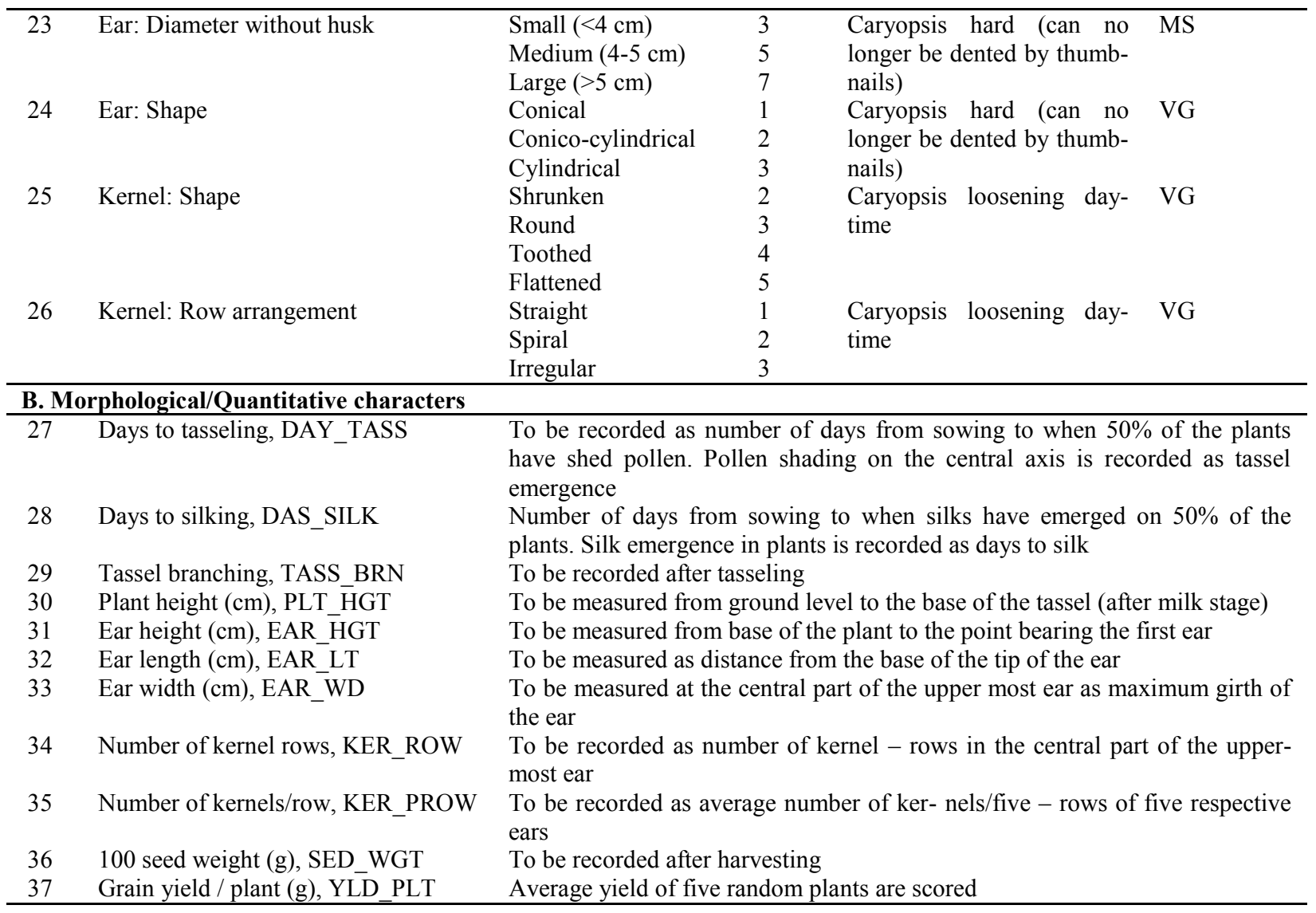

Table 2. Mean performance of three replications for various morphological characteristics in maize (kharif 2011 and 2012 ).

\begin{tabular}{|c|c|c|c|c|c|}
\hline \multirow{2}{*}{ S. N. } & \multirow{2}{*}{ Observations } & \multicolumn{4}{|c|}{ Genotypes } \\
\hline & & AAIMS-1 & AAIMS-2 & MRM-3777 & SUPER-36 \\
\hline 1 & Days to $50 \%$ tasseling & $\begin{array}{c}50.66^{*} \\
(50.66)^{* *}\end{array}$ & $\begin{array}{c}51.33^{*} \\
52.00^{* *}\end{array}$ & $\begin{array}{c}52.33^{*} \\
53.66^{* *}\end{array}$ & $\begin{array}{c}52.66^{*} \\
54.66^{* *}\end{array}$ \\
\hline 2 & Days to $50 \%$ silking & $\begin{array}{c}53.66^{*} \\
53.66^{* *}\end{array}$ & $\begin{array}{c}54.33^{*} \\
54.66^{* *}\end{array}$ & $\begin{array}{c}55.33^{*} \\
56.66^{* *}\end{array}$ & $\begin{array}{c}56.00^{*} \\
57.33^{* *}\end{array}$ \\
\hline 3 & Anthesissilking interval & $\begin{array}{c}3.000^{*} \\
2.666^{* *}\end{array}$ & $\begin{array}{c}3.000^{*} \\
3.000^{* *}\end{array}$ & $\begin{array}{c}3.333^{*} \\
3.000^{* *}\end{array}$ & $\begin{array}{c}3.000 * \\
3.000 * *\end{array}$ \\
\hline 4 & Tassel branching & $\begin{array}{c}22.66^{*} \\
21.66^{* *}\end{array}$ & $\begin{array}{c}22.33^{*} \\
20.66^{* *}\end{array}$ & $\begin{array}{c}20.33^{*} \\
19.66^{* *}\end{array}$ & $\begin{array}{c}22.33^{*} \\
20.00^{* *}\end{array}$ \\
\hline 5 & Plant height & $\begin{array}{c}151.86^{*} \\
153.71 * *\end{array}$ & $\begin{array}{c}155.13^{*} \\
149.06^{* *}\end{array}$ & $\begin{array}{c}141.53^{*} \\
142.91 * *\end{array}$ & $\begin{array}{c}142.63 * \\
143.68 * *\end{array}$ \\
\hline 6 & Cob height & $\begin{array}{c}89.70^{*} \\
89.16^{* *}\end{array}$ & $\begin{array}{c}88.30^{*} \\
88.80^{* *}\end{array}$ & $\begin{array}{c}85.35^{*} \\
85.48^{* *}\end{array}$ & $\begin{array}{c}86.05^{*} \\
85.50^{* *}\end{array}$ \\
\hline 7 & Days to maturity & $\begin{array}{c}87.33^{*} \\
88.00^{* *}\end{array}$ & $\begin{array}{c}86.00^{*} \\
87.00^{* *}\end{array}$ & $\begin{array}{c}89.00^{*} \\
90.00^{* *}\end{array}$ & $\begin{array}{c}89.66^{*} \\
89.66^{* *}\end{array}$ \\
\hline 8 & Cob length & $\begin{array}{c}16.96^{*} \\
17.75^{* *}\end{array}$ & $\begin{array}{c}16.93 * \\
16.63 * *\end{array}$ & $\begin{array}{c}13.76^{*} \\
13.33^{* *}\end{array}$ & $\begin{array}{c}14.20^{*} \\
14.05^{* *}\end{array}$ \\
\hline 9 & Cob width & $\begin{array}{c}12.51^{*} \\
13.11^{* *}\end{array}$ & $\begin{array}{c}12.66^{*} \\
13.90^{* *}\end{array}$ & $\begin{array}{c}10.63^{*} \\
11.41^{*} *\end{array}$ & $\begin{array}{c}10.96^{*} \\
11.56^{* *}\end{array}$ \\
\hline 10 & Number of grain rows per cob & $\begin{array}{c}12.66^{*} \\
12.66^{* *}\end{array}$ & $\begin{array}{c}13.33^{*} \\
13.33^{* *}\end{array}$ & $\begin{array}{c}10.66^{*} \\
11.33^{* *}\end{array}$ & $\begin{array}{c}11.33^{*} \\
10.66^{* *}\end{array}$ \\
\hline 11 & Grain yield per plant & $\begin{array}{c}71.30^{*} \\
72.00^{* *}\end{array}$ & $\begin{array}{c}72.80^{*} \\
71.47^{* *}\end{array}$ & $\begin{array}{c}55.69^{*} \\
64.12^{* *}\end{array}$ & $\begin{array}{c}56.05^{*} \\
64.63^{* *}\end{array}$ \\
\hline 12 & 100 seed weight & $\begin{array}{c}20.96^{*} \\
20.96^{* *}\end{array}$ & $\begin{array}{c}21.51^{*} \\
20.65^{* *}\end{array}$ & $\begin{array}{c}17.63^{*} \\
18.10^{* *}\end{array}$ & $\begin{array}{c}19.28^{*} \\
19.11^{* *}\end{array}$ \\
\hline
\end{tabular}

*kharif 2011 and $* *$ kharif 2012,3 replications 
Table 3. Pooled physiological characterization of visually assessed characteristics of maize (kharif 2011 and 2012).

\begin{tabular}{|c|c|c|c|c|c|}
\hline \multirow{2}{*}{ S. $\mathbf{N}$. } & \multirow{2}{*}{ Characteristics } & \multicolumn{4}{|c|}{ Genotypes } \\
\hline & & AAIMS-1 & AAIMS-2 & MRM-3777 & SUPER-36 \\
\hline 1 & Leaf: angle between blade and stem & Narrow & Narrow & Wide & Narrow \\
\hline 2 & Leaf: attitude of blade & Drooping & Erect & Drooping & Drooping \\
\hline 3 & Leaf: anthocyanin colouration of blade \& sheath & Present & Absent & Present & Present \\
\hline 4 & Leaf: hairs on the blade & Present & Absent & Absent & Present \\
\hline 5 & Leaf: anthocyanin colouration of auricle & Present & Present & Absent & Present \\
\hline 6 & Leaf: hairs on the auricle & Present & Present & Absent & Present \\
\hline 7 & Stem: anthocyanin colourtion of stem & Absent & Absent & Absent & Absent \\
\hline 8 & Stem: anthocyanin colouration of brace roots & Present & Absent & Present & Present \\
\hline 9 & Tassel: time of anthesis & Early & Medium & Late & Medium \\
\hline 10 & Tassel: anthocyanin colouration at base of glume & Present & Present & Absent & Present \\
\hline 11 & $\begin{array}{l}\text { Tassel: anthocyanin colouration of glumes excluding } \\
\text { base }\end{array}$ & Present & Present & Absent & Present \\
\hline 12 & Tassel: anthocyanin colouration of anthers & Absent & Present & Absent & Present \\
\hline 13 & Tassel: density of spikelets & Dense & Dense & Sparse & Dense \\
\hline 14 & Tassel: attitude of lateral branches & Straight & Straight & Curve & Straight \\
\hline 15 & Ear: anthocyanin colouration of silks & Present & Present & Present & Present \\
\hline 16 & Ear: time of silk emergence $(50 \%$ plants $)$ & Early & Medium & Late & Medium \\
\hline 17 & Ear: anthocyanin colouration of glumes of cob & White & White & Light purple & Dark purple \\
\hline 18 & Ear: type of grain & Flint & Flint & Dent & Semi flint \\
\hline 19 & Ear: colour of top of grain & White & White & White with cap & Yellow \\
\hline 20 & Ear: shape & Cylindrical & Cylindrical & Conical & $\begin{array}{l}\text { Conico- } \\
\text { cylindrical }\end{array}$ \\
\hline 21 & Kernel: shape & Shrunken & Round & Flattened & Toothed \\
\hline 22 & Kernel: Row arrangement & Straight & Spiral & Irregular & Irregular \\
\hline
\end{tabular}

Table 4. States of different measurable physiological characteristics with over years mean performance of three replications for four maize genotypes (kharif 2011 and 2012).

\begin{tabular}{lcccc}
\hline \multirow{2}{*}{ Genotypes } & \multicolumn{4}{c}{ Characteristics } \\
\cline { 2 - 5 } & $\begin{array}{c}\text { Tassel: length of main axis } \\
\text { above lowest side branch (cm) }\end{array}$ & $\begin{array}{c}\text { Plant: ear placement } \\
\mathbf{( c m )}\end{array}$ & $\begin{array}{c}\text { Leaf: width of blade } \\
\text { (cm) }\end{array}$ & $\begin{array}{c}\text { Ear: diameter } \\
\text { without husk (cm) }\end{array}$ \\
\hline AAIMS-1 & Long (42.25) & Medium (70.20) & Medium (8.07) & Long (7.60) \\
AAIMS-2 & Long (42.27) & Medium (71.18) & Medium (8.30) & Medium (4.95) \\
MRM-3777 & Long (40.40) & Low (58.07) & Narrow (6.55) & Medium (4.86) \\
SUPER-36 & Long (41.86) & High (73.20) & Broad (9.47) & Long (6.90) \\
\hline
\end{tabular}

Table 5. Pairwise distinctiveness matrix of maize genotypes obtained from COYD analysis.

\begin{tabular}{llcccc}
\hline S. N. & Candidate genotypes & AAIMS-1 & AAIMS-2 & MRM-3777 & SUPER-36 \\
\hline 1 & AAIMS-1 & - & $\mathrm{D}$ & $\mathrm{D}$ & $\mathrm{D}$ \\
2 & AAIMS-2 & $\mathrm{D}$ & - & $\mathrm{D}$ & $\mathrm{D}$ \\
3 & MRM-3777 & $\mathrm{D}$ & $\mathrm{D}$ & - & $\mathrm{D}$ \\
4 & SUPER-36 & $\mathrm{D}$ & $\mathrm{D}$ & $\mathrm{D}$ & - \\
& Overall distinctiveness & $\mathrm{D}$ & $\mathrm{D}$ & $\mathrm{D}$ & $\mathrm{D}$ \\
\hline
\end{tabular}

$\mathrm{D}=$ Distinctiveness

Table 6. Combination over year's uniformity analysis of four measurable characteristics.

\begin{tabular}{lllll}
\hline Candidate genotypes & $\begin{array}{l}\text { Tassel: length of main axis } \\
\text { above lowest side branch }\end{array}$ & $\begin{array}{l}\text { Plant: ear place- } \\
\text { ment }\end{array}$ & $\begin{array}{l}\text { Leaf: width of } \\
\text { blade }\end{array}$ & $\begin{array}{l}\text { Ear: diameter with- } \\
\text { out husk }\end{array}$ \\
\hline AAIMS-1 & 96 & 94 & $112(1)$ & $126(1)$ \\
AAIMS-2 & 98 & 99 & 83 & 97 \\
MRM-3777 & 105 & 104 & 99 & 116 \\
SUPER-36 & 103 & 98 & 102 & $110(1)$ \\
\hline
\end{tabular}

Symbol: 1 Number of occasions the within years. SD exceeds the UPOV criterian

expressivity is affected by environment due to gene $x$ environment interaction (Law et al 2011a).

The objective of this study was to determine the potential utility of morphological and physiological characters for application in research, product development, seed production, intellectual property right (IPR) and genetic resource conservation management in maize. To accomplish this goal, we assessed the discrimination ability of data obtained from morphology and physiology. The present investigation was conducted to study the comparative evaluation of maize (Zea mays L.) genotypes based on distinctness, uniformity 
Table 7. Statistical analysis for stability by comparison of respective values of Genetic parameters for four measurable characters based on morphological data (kharif 2011 and kharif 2012).

\begin{tabular}{llcccccc}
\hline S. N. & Character & VG & VP & GCV\% & PCV\% & $\mathbf{h}^{2}$ (Broad Sence) & GA \\
\hline \multirow{2}{*}{1} & Tassel: length of main axis & $0.761^{*}$ & $1.288^{*}$ & $1.351^{*}$ & $1.752^{*}$ & $59.08^{*}$ & $1.37^{*}$ \\
& above lowest side branch & $0.742^{* *}$ & $1.298^{* *}$ & $1.317^{* *}$ & $1.763^{* *}$ & $57.16^{* *}$ & $1.33^{* *}$ \\
2 & Plant: ear placement & $74.50^{*}$ & $78.92^{*}$ & $10.375^{*}$ & $10.685^{*}$ & $94.39^{*}$ & $17.26^{*}$ \\
& & $58.33^{* *}$ & $59.32^{* *}$ & $9.173^{* *}$ & $9.251^{* *}$ & $98.33^{* *}$ & $15.5^{* *}$ \\
3 & Leaf: width of blade & $1.263^{*}$ & $1.587^{*}$ & $3.941^{*}$ & $4.418^{*}$ & $79.58^{*}$ & $2.04^{*}$ \\
& \multirow{2}{*}{ Ear: diameter without husk } & $1.453^{* *}$ & $1.596^{* *}$ & $18.027^{* *}$ & $4.449^{* *}$ & $91.04^{* *}$ & $2.36^{* *}$ \\
& $2.002^{*}$ & $2.403^{*}$ & $5.733^{*}$ & $6.281^{*}$ & $83.31^{*}$ & $2.66^{*}$ \\
& & $1.558^{* *}$ & $2.058^{* *}$ & $5.308^{* *}$ & $5.827^{* *}$ & $75.70^{* *}$ & $2.23^{* *}$ \\
\hline
\end{tabular}

*kharif2011 and $* *$ kharif 2012

these genotypes is at the lowest level of number of occasions at which the within years standard deviation exceeds the UPOV criterion and for stability, there was no variation in expression of these characteristics over the years. So, based on these results, it can be concluded that morphological and physiological DUS descriptors can be effectively used for identification and grouping of varieties. The morphological and physiological descriptors used in the present study may be used for DUS criteria for establishment of distinctness of maize varieties and as such more trials should be carried out to validate the findings.

\section{ACKNOWLEDGEMENT}

The authors are thankful to Head, Department of Genetics and Plant Breeding, Sam Higginbottom Institute of Agriculture, Technology and Sciences, (Formerly Allahabad Agricultural Institute) (Deemedto-be-University) Allahabad (U.P.) for the facilities provided during the experiment.

\section{REFERENCES}

Agriculture statistics at a glance (2015). Directorate of Economic and statistics, ministry of Agricultural Government of India.

Akande, S.R. and Lamidi, G.O. (2006). Performance of quality protein maize varieties and disease reaction in the derived-savanna agro-ecology of South-West Nigeria, African journal of biotechnology, 5(19): 1744-1748.

Anonymous (2014). Maize in India- India maize summit 2014 National Commodity and Derivatives Limited, New Delhi, pp. 7.

Begum, T. and Kumar, D. (2011). Usefulness of morphological characteristics for DUT testing of jute (Corchorus olitorius L. and C. capsularis L.) Spanish Journal of Agricultural Research. 9:473-483.

Beyene, Y.A., Botha, A. and Myburg, A.A. (2005). A comparative study of molecular and morphological methods of describing genetic relationship in traditional Ethiopian highland maize. African journal of biotechnology. 4:586-595.

Jha, P.B. and Ghosh, J. (1998). Genetic variability in fodder maize. Journal of Research, Birsa Agricultural University, 10:139-143.

Law, J.R., Anderson, S.R., Jones, E.S., Nelson, B.K., Mulaosmanovic, E. and Smith, J.S. (2011). Characterization of maize germplasm: Comparison of morphological datasets compiled using different approaches to data recording. Maydica 56:1708-1711.

Law, J.R., Anderson, S.R., Jones, E.S., Nelson, B., Mulaosmanovic, E., Hall, B.D. and Smith, S.C. (2011a). Approaches determination of eligibility for plant variety protection: evaluation of morphological characteristics. Maydica 56:113-131.

Olaoye, G. (2009). Evaluation of new generation maize steak virus (MSV) resistant maize varieties for adaptation to southern guinea savanna ecology of Nigeria. African Journal of Biotechnology. 8 (19): 4906-4910.

Smykal, P., Horacek, J., Dostalova, J. and Hybl, M. (2008). Variety discrimination in pea (Pisum sativum L.) by molecular, biochemical and morphological markers. Applied genetics. 49:155-166.

Yadav, V.K. and Singh, V.K. (2010).Comparative evaluation of maize inbred lines (Zea mays L.) according to dus testing using morphological, physiological and molecular markers. Agricultural Sciences, 1(3):131-142.

Olakojo, S.A. and Olaoye, G. (2005). Combining ability for grain yield, agronomic traits and Striga lutea tolerance of maize hybrids under artificial Striga infestation. African Journal of Biotechnology. 4(9): 984-988.

Nazir, H., Zaman, Q. Amjad, M. Nadeeman A. and Aziz. J. (2010). Response of maize varieties under agroecological conditions of Dera Ismail khan. Journal of Agriculture Research. 48(1): 59-63.

Salami, A.E., S.A.O. Adegoke and O.A. Adegbite. (2007). Genetic variability among maize cultivars grown in Ekiti-State, Nigeria. Middle-East Journal of Science Research. 2(1): 09-13. 